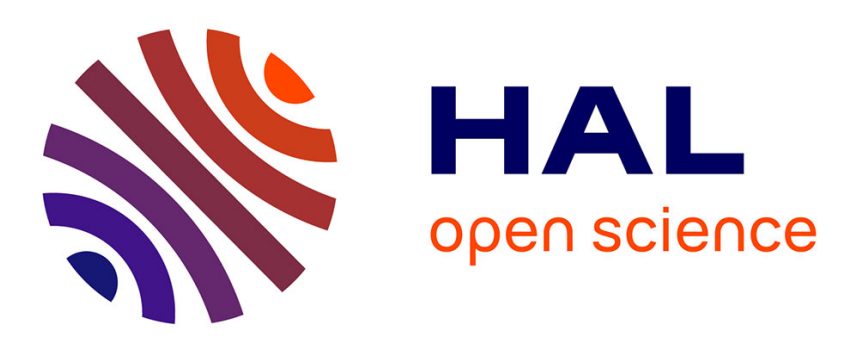

\title{
Culture of Borrelia persica and its flagellar antigen in vitro.
}

\author{
Zahra Zamani, Mohammad Arjmand, Farzad Oreiz, Mohammad Soleimani, \\ Seyed Hossein Hosseini, Mehdi Assmar, Saifeddin Javadian, Reza Saghiri, \\ Fatemeh Pourfallah
}

\section{To cite this version:}

Zahra Zamani, Mohammad Arjmand, Farzad Oreiz, Mohammad Soleimani, Seyed Hossein Hosseini, et al.. Culture of Borrelia persica and its flagellar antigen in vitro.. Pakistan Journal of Biological Sciences, 2014, 17 (2), pp.190-7. 10.3923/pjbs.2014.190.197 . pasteur-01057589

\section{HAL Id: pasteur-01057589 https://hal-riip.archives-ouvertes.fr/pasteur-01057589}

Submitted on 24 Aug 2014

HAL is a multi-disciplinary open access archive for the deposit and dissemination of scientific research documents, whether they are published or not. The documents may come from teaching and research institutions in France or abroad, or from public or private research centers.
L'archive ouverte pluridisciplinaire HAL, est destinée au dépôt et à la diffusion de documents scientifiques de niveau recherche, publiés ou non, émanant des établissements d'enseignement et de recherche français ou étrangers, des laboratoires publics ou privés. 
Pakistan Journal of Biological Sciences 17 (2): 190-197, 2014

ISSN 1028-8880 / DOI: 10.3923/pjbs.2014.190.197

(C) 2014 Asian Network for Scientific Information

\title{
Culture of Borrelia persica and its Flagellar Antigen in vitro
}

\author{
${ }^{1}$ Zahra Zamani, ${ }^{1}$ Mohammad Arjmand, ${ }^{2}$ Farzad Oreiz, ${ }^{2}$ Mohammad Soleimani, ${ }^{3}$ Seyed Hossein Hosseini, \\ ${ }^{2}$ Mehdi Assmar, ${ }^{1}$ Saifeddin Javadian, ${ }^{1}$ Reza Saghiri and ${ }^{1}$ Fatemeh Pourfallah \\ ${ }^{1}$ Department of Biochemistry, Pasteur Institute of Iran, Pasteur Ave., Tehran, 1316943551, Iran \\ ${ }^{2}$ Department of Parasitology, Pasteur Institute of Iran, Pasteur Ave., Tehran, 1316943551, Iran \\ ${ }^{3}$ Department of Immunology, Razi Institute of Serology, Sanaye Sq., Shiraz, 7188843568, Iran
}

\begin{abstract}
Borrelia persica is a strain seen only in the Middle East and responsible for relapsing fever. These spirochetes are notable for multiphasic antigenic variation of polymorphic outer membrane lipoproteins, a phenomenon responsible for immune evasion. Diagnosis of the disease is a problem and requires a fixed antigen like the flagellar antigen. In vitro culture of $B$. persica was carried out for the first time and flagellar antigen was purified from culture. $10 \%$ SDS was added to the mixture to dissolve the cell wall and then the solution was sheared in an Omni mixer. Electron microscopy confirmed the purity of a $42 \mathrm{KDa}$ periplasmic antigen as revealed by SDS-PAGE. Indirect haemagglutination kits were designed using the pure flagella and tested for cross reactivity with another relapsing fever spirochaete Borrelia microtii positive serum. The kit showed $98 \%$ sensitivity and $95 \%$ specificity.
\end{abstract}

Key word: Borrelia persica, relapsing fever, indirect hemagglutination kit

\section{INTRODUCTION}

The genus Borrelia comprises the arthropod vectortransmissible spirochetes. These organisms are responsible for two groups of human disease: lyme borreleosis, which is transmitted by the hard Ixodes ticks and relapsing fever; most of which are transmitted by the soft ticks (Agrasidae), the exception being a louse borne relapsing fever which is transmitted by Pediculus humanus (Barbour et al., 1983). Borrelia hermsii, Borrelia parkeri, B. turicatae and B. duttoni are etiological agents of louse-borne relapsing disease (Burgdorfer and Schwann, 1999). In Iran, the species which cause relapsing fever are Borrelia persica, Borrelia latschywii, Borrelia microttii and Borrelia balthazardi, each of which is responsible for spread of the disease in certain areas of the country. Borrelia persica (B. persica) was discovered in Iran by Dschunkowsky in 1913 in the northeast region of Ardebil. Its vector is the tick Ornithodorous thollazoni (O.thollazoni) (Karimi et al., 1979).

Relapsing fever is characterized by fever followed by septicemia. The high fevers of infected patients spontaneously abate and then recur. This characteristic pattern of remission and relapse not only gives relapsing fever its name but also allows it to be differentiated clinically from other febrile illnesses as it has since the $1840 \mathrm{sec}$ (Dworkin et al., 2008).
The relapse phenomenon occurs because of genetically programmed shifting of outer surface proteins of the Borrelia that allows a new clone to avoid destruction by antibodies directed against the majority of the original infecting organisms (Porcella et al., 2005). Thus, the person clinically improves until the new clone multiplies sufficiently to cause another relapse.

Between bouts, no Borrelia is perceived in the blood, but it may be identified in the spleen, liver or the intestines. Humoral immunity rather than cellular immunity seems to play a part in recovery from and immunity to relapsing fever (LaRocca and Benach, 2008). Diagnosis of Borrelia is carried out by a number of methods: Direct smear is the only specific method for diagnosis of Borrelia in blood (although only $70 \%$ of the patients have Borrelia in their blood at any given time). In vivo culture of blood in experimental animals can be also used for diagnosis (Stoenner et al., 1982). Only guinea pigs and rabbits get fever due to $B$. persica and not mice and rats which are used for $B$. microtti another Iranian strain; these animals are used for in vivo diagnosis (Schwann and Hinnebush, 1998), but, serology is now the main method of diagnosis (Wojciechowska-Koszko et al., 2011).

Surface targets of host immunity and potential virulence factors are the outer membrane proteins. The characterization of these rare outer membrane proteins in an organism that undergo antigenic variation is important

Corresponding Author: Fatemeh Pourfallah, Department of Biochemistry, Pasteur Institute of Iran, Pasteur Ave., Tehran, 1316943551, Iran 
for understanding the pathogenesis of relapsing fever and potentially relevant to the development of an efficacious vaccine. But, for serological diagnosis a fixed antigen is required (Lopez et al., 2009, 2010). The flagella on the surface of the pathogen are one of the first antigens against which antibodies are formed (Hansen et al., 1988). Flagella has been identified as the first antigen to which IgM respond if formed and is used for diagnosis in Lyme disease, IgG levels to other antigens do not show any change after treatment but antibody level to flagellin show a distinct decrease after successful treatment and hence can be used as a marker for termination of Lyme borreleosis (Panelius et al., 2010; Burbelo et al., 2010). In vitro culture of different Borrelia has been reported but Borrelia persica has proven to be difficult as reported by Farrah et al. (2010).

A culture of B. persica was set up for the first time and the flagellar antigen purified by the technique of Assmar et al. (2002b) and used for preparation of a serological kit involving an indirect haemmaglutination assay.

\section{MATERIALS AND METHODS}

Spirochetes: Iranian strains of the spirochetes B. persica and $B$. microti strains were maintained in $O$. thollazoni and $O$. erraticus ticks. Inoculation of guinea pigs was carried out by tick bites of $O$. thollazoni. B. microtti was introduced in a similar manner in white mice. Infected animals suffered from 2-3 bouts of fever of 1-2 day duration, interspersed with $3 \mathrm{~d}$ without fever, a typical picture of relapsing fever. In guinea pigs, when the number of Borrelia reached 20-30 per field (dark field microscopy (X40) (Assmar et al., 2002a) blood was collected and injected into other guinea pigs for in vivo maintenance.

In vitro cell culture: Cells were cultivated in vitro in BSK medium (SIGMA, USA) $7 \%$ gelatin and $10 \%$ sera. An important component is $10 \%$ rabbit serum which was replaced with either fetal calf serum or guinea pig serum. The cells were incubated $\left(35^{\circ} \mathrm{C}\right.$ for $5 \mathrm{~d}$ ) in $18 \times 80 \mathrm{~cm}$ tubes with Teflon lids, filled $2 \mathrm{cms}$ from the top of the tube. Counts were carried out at different times and the generation period for each one calculated.

Infected sera: Were obtained from blood of 60 guinea pigs immunized with $B$. persica and 60 mice immunized with $B$. microtti. Sera from normal non immunized mice and guinea pigs were used as negative controls. Sera were preserved at $-70^{\circ} \mathrm{C}$ (Assmar et al., 2002b).

Sonicated antigen: Borrelia was grown in $500 \mathrm{~mL}$ BSK medium and a $3 \mathrm{~d}$ growth culture of Borrelia. Cells were harvested by centrifugation at 7,000 $\mathrm{g}$ for $20 \mathrm{~min}$ and then suspended in $10 \mathrm{~mL}$ physiological saline. The suspension obtained was sonicated on ice at $90 \mathrm{~Hz} \mathrm{sec}$ for $5 \mathrm{~min}$ and then centrifuged at $10,000 \mathrm{~g}$ for $30 \mathrm{~min}$ at $4^{\circ} \mathrm{C}$. The supernatant was designated as antigen of $B$. persica and stored at $-70^{\circ} \mathrm{C}$ (Assmar et al., 2002b).

Purification of flagellar antigen: Borrelia cells $\left(3 \times 10^{10}\right)$ obtained from 31 of BSK media were centrifuged at $7,000 \mathrm{~g}$ for $20 \mathrm{~min}$ at $20^{\circ} \mathrm{C}$ and washed 4 times with sterile physiological saline and then suspended in $50 \mathrm{~mL}$ normal saline. Sodium dodecyl sulphate (SDS-Merck, Germany) concentrations $(0.005-0.04 \%)$ were added to the cells, which were then maintained for $20 \mathrm{~min}$ at room temperature. They were then centrifuged at $25,000 \mathrm{~g}$ at $4^{\circ} \mathrm{C}$. The suspension obtained contained outer envelope protein and was filtered using a $0.22 \mu$ filter and SDS removed by dialysis for $18 \mathrm{~h}$ in PBS containing $30 \mathrm{mM}$ $\mathrm{MgCl}_{2}$ (MERCK Germany) and stored at $-70^{\circ} \mathrm{C}$ and named as outer envelope fraction.

Flagella: The precipitate acquired for the technique described above was suspended in $50 \mathrm{~mL}$ sterile normal saline and the suspension sheared for $5 \mathrm{~min}$ in an Omni mixer at $16,000 \mathrm{~g}$ and then centrifuged at $25,000 \mathrm{~g}$ for $40 \mathrm{~min}$ at $4{ }^{\circ} \mathrm{C}$ and the supernatant collected each time in the same way, concentrated using PEG 6000 (Merck, Germany) and then dialyzed against 201 of PBS. The protein obtained was designated as periplasmic flagellar protein (pf protein).

SDS-polyacrylamide gel electrophoresis: was carried out by Laemmeli, 1972,s technique 1972, Standard molecular markers of $29,34,66$ and $210 \mathrm{KD}$ were used (Sigma, USA). Samples ( $20 \mu \mathrm{L}$ ) were mixed with buffer containing 2-mercaptoethanol and SDS and boiled for $2 \mathrm{~min}$; they were electrophoressed on $13 \times 10 \mathrm{~mm}^{2}$ gels containing 5\% stacking gel and $12 \%$ resolving gel, using $18 \mathrm{~mA}$ for the stacking gel and $24 \mathrm{~mA}$ for the resolving gel. Gels were stained with silver (Blum et al., 1987). Protein was measured throughout using Bradford (1976).

Electron microscopy: Was done by the method of (Garon 1981). The $3 \mu \mathrm{L}$ of different samples were placed on 300 mesh grids, treated with parlodin (Sigma, USA) for $30 \mathrm{~min}$ at room temperature, washed with distilled water and then stained with $1 \%$ Uranyl acetate (Sigma, USA). Samples were visualized using Hitachi electron microscope.

Counter immunoelectrophoresis: Was carried out using purified flagellar antigen and antibody positive serum by using barbiturate buffer (Merck, Germany, $\mathrm{pH}$ 8.2) and 50 $\mathrm{mA}$ current for $90 \mathrm{~min}$ (Sherris et al., 2004). 
Dot blotting: Purified flagellar protein was blotted on nitrocellulose and then incubated with positive serum then with secondary anti guinea pig peroxidase conjugated antibody. Bands were visualized with $\mathrm{DAB}$ and hydrogen peroxide (Merck, Germany) (Sherris et al., 2004).

Indirect hemagglutination assay: (IHA) Sheep red blood cells were washed and sensitized with tannic acid and coated with sonicate $\left(700 \mathrm{mg} \mathrm{mL}^{-1}\right.$ ) or flagellar protein ( $400 \mathrm{mg} \mathrm{mL}^{-1}$ ). The test was carried out on 60 serum samples from mice immunized with $B$. persica and 60 mice immunized with B. microtti as test samples and 60 serum samples from non-immunized mice as controls (Herbert 1978).

Statistical analysis: The geometric mean reverse titre (GMRT) and student's $t$ test were used for IHA-sonicate and flagella.

\section{RESULTS}

The best results were seen in BSK medium with 10\% guinea pig serum (Fig. 1,2). The lag phase of B. persica ranged from 18 to 24 hours and was followed by the log phase of 24-96 $\mathrm{h}$ and then a stationary phase of 96-112 $\mathrm{h}$ then followed by cell death. The number of cells obtained in this medium was 140 million $\mathrm{mL}^{-1}$ and the generation time was $10.97 \mathrm{~h}$.

As guinea pig serum was difficult to obtain, fetal calf serum, which showed only a little difference between the time and number of cells produced was used instead for large production of Borrelia proteins. Rabbit serum did not give good results (Fig. 1). Bacteria collected in this way were used for flagellar purification. The outer envelope of bacteria was removed with SDS. Flagella on the outer surface of the bacteria were revealed after $5 \mathrm{~min}$ treatment with SDS and electron microscopy clearly showed flagella on the outer surface of the cells (Fig. 3). An outer envelope protein showed 2 bands at 31 and $34 \mathrm{KD}$ on SDS-PAGE and by increasing the detergent concentration from 0.005 to $0.04 \%$ a larger amount of protein from the outer envelope of the cell was seen. There was an obvious relationship between SDS and outer envelope protein where at concentrations $>0.04 \%$ the $42 \mathrm{KDa}$ flagellin contaminated the outer envelope fraction. The concentration of SDS was standardized to $0.3 \%$ as it exhibited the greatest amount of flagellin in the protoplasmic cylinder fraction (Fig. 4); higher concentrations resulted in destruction of the protoplasmic cylinder fractions, as detected by electron microscopy.
Protoplasmic cylinders which had settled in the precipitate and the supernatant contained outer envelope fractions. SDS PAGE showed that the protoplasmic cylinder fractions contained a large amount of $42 \mathrm{KDa}$ flagellin (fig.4 lane D). Electron microscopy revealed flagella at this stage (Fig. 4) and the concentrated precipitant showed a lot of flagella (Fig. 4 lane B). In this study, $3.3 \mathrm{mg}$ of flagellin was obtained from $5 \times 10^{10}$ cells.

Serology: Counter-immunoelectrophoresis and dot blotting was carried out showing a high sensitivity of the flagellar protein for the antibody positive serum. The IHA flagella kit was tested on $50 \mathrm{~B}$. microtti positive sera, 50 $B$. persica positive sera and 60 normal sera that were used as negative controls (Table 1). GMRT of anti Borrelia sera was calculated to obtain specificity and sensitivity of kit (Fig. 5). The kits showed 98\% sensitivity and

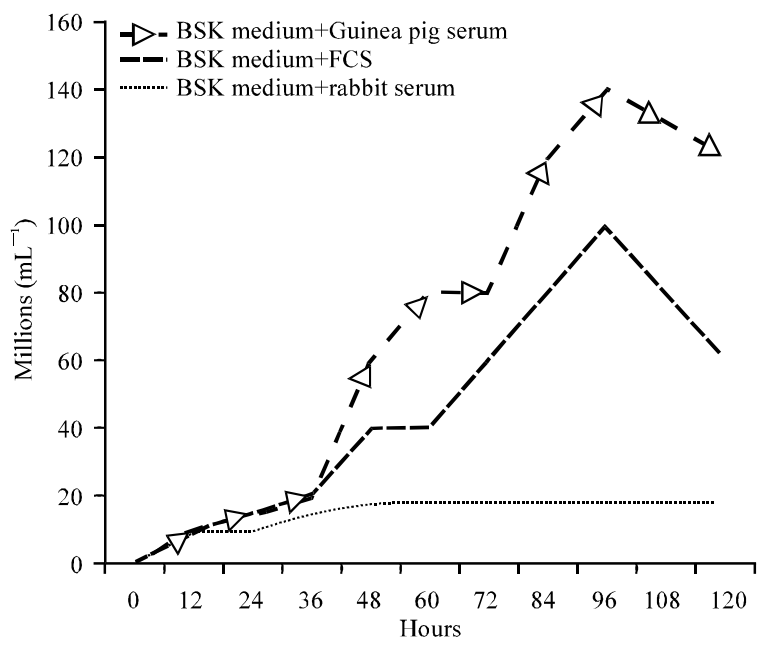

Fig. 1: Growth curve of $B$. persica in BSK medium containing different animal sera

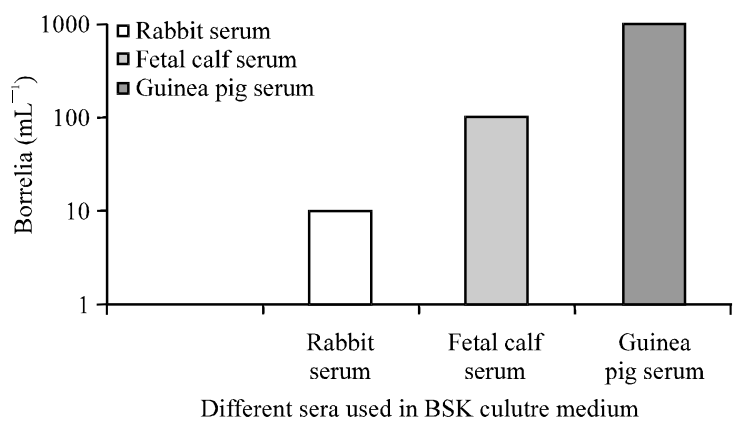

Fig. 2: Effect of different sera in BSK medium on B. persica growth 

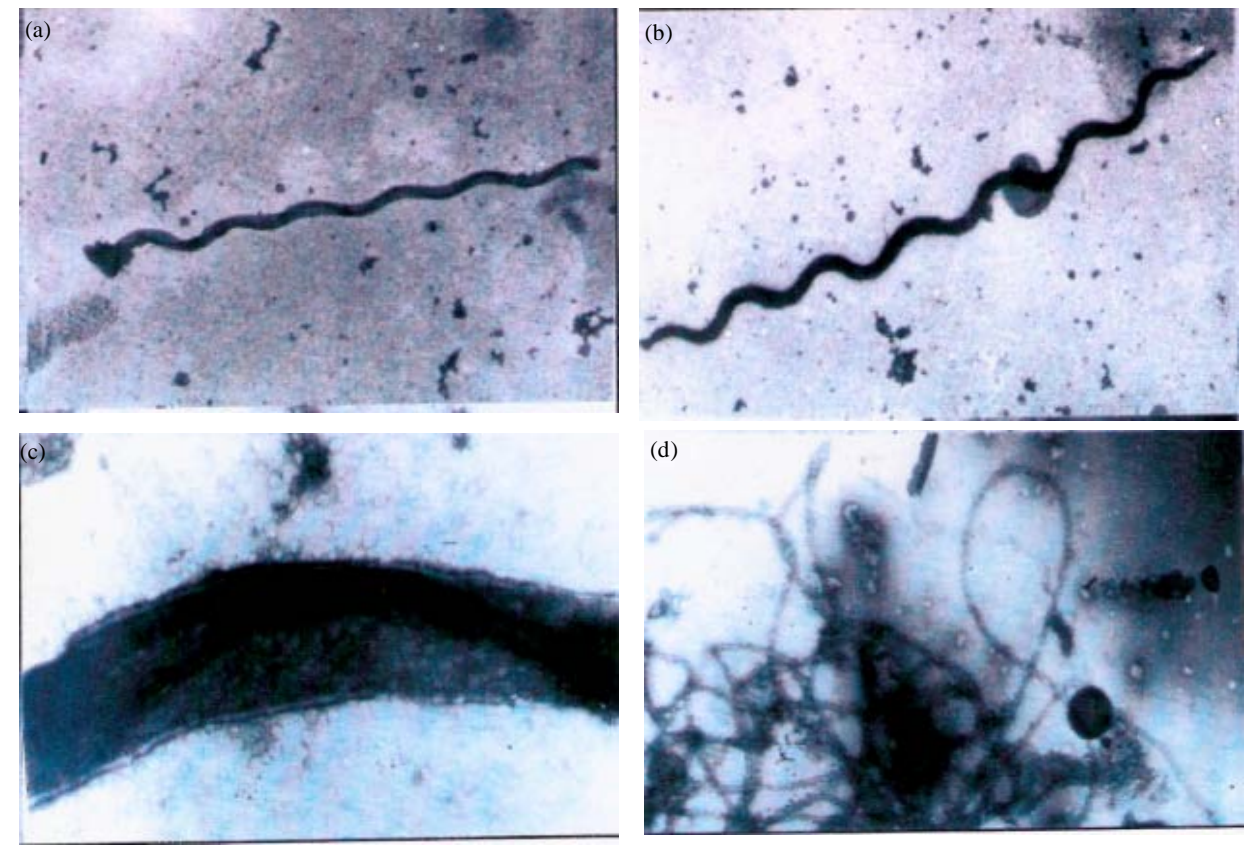

Fig. 3(a-d): Electron microscopic photographs of different stages of Borrelia persica periplasmic flagellar purification (a) B. persica original magnification (OM) X15,000, (b) B.persica after 5 min treatment with $0.03 \%$ SDS $(\mathrm{OM} \times 15,000)$, (c) B. persica after 10 min treatment with $0.03 \% \mathrm{SDS}(\mathrm{OM} \times 20,000)$ and (d) Pure flagella of B. persica $(\mathrm{OM} \times 250,000)$

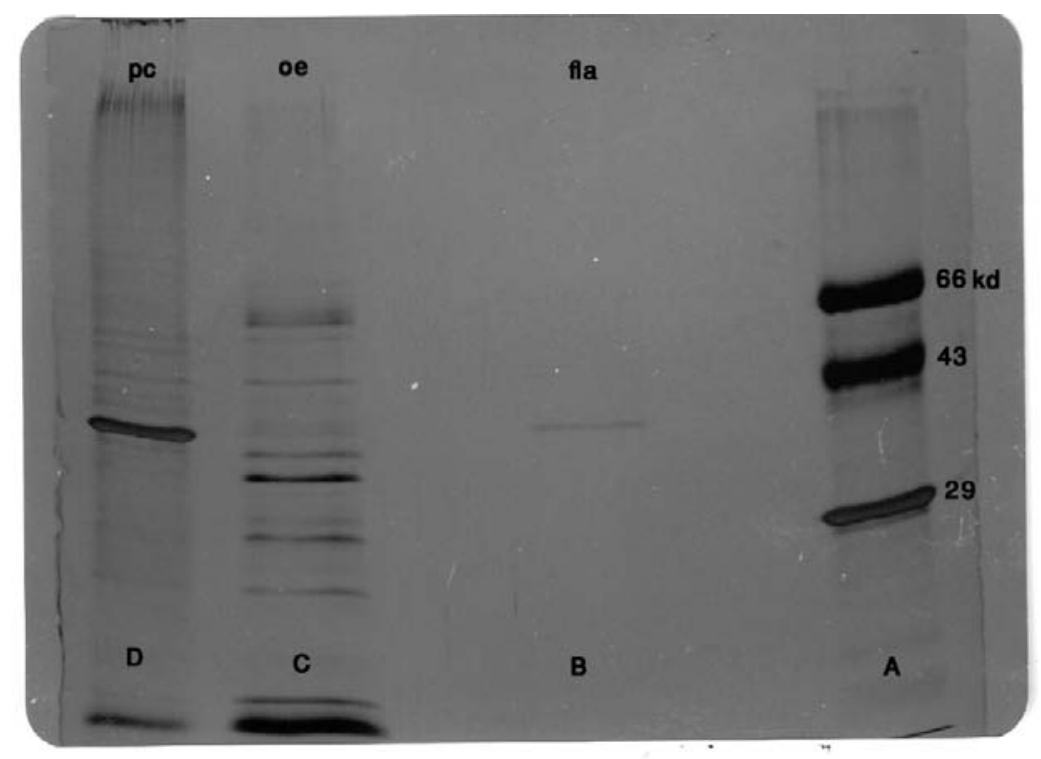

Fig. 4: 10\% SDS-PAGE of Borrelia persica using silver staining: Lane A: Standard molecular weight markers, Lane B: Pure periplasmic flagellar antigen Lane C: Outer protein extract purified periplasmic flagellar protein Lane D: protoplasmic cylinder 
Pak. J.Biol. Sci., 17 (2): 190-197, 2014

Table 1: Cross reactivity of flagellar antigens of $B$. presica and B. microtti using $B$. persica IHA flagellar kit

\begin{tabular}{|c|c|c|c|c|c|c|c|c|c|c|}
\hline \multirow[b]{2}{*}{ Inoculation } & \multirow[b]{2}{*}{ No. of samples } & \multirow[b]{2}{*}{ No. of positive } & \multirow[b]{2}{*}{ No. negative } & \multicolumn{6}{|c|}{ Antibody titre } & \multirow[b]{2}{*}{$\mathrm{GMRT}^{*}$} \\
\hline & & & & $1 / 2$ & $1 / 4$ & $1 / 8$ & $1 / 16$ & $1 / 32$ & $1 / 64$ & \\
\hline B. persica & 50 & 45 & 5 & 1 & 2 & 5 & 8 & 25 & 4 & 45.3 \\
\hline B. microttii & 50 & 29 & 21 & 16 & 9 & 3 & 1 & 0 & 0 & 3.25 \\
\hline Non immunized animals & 50 & 12 & 38 & 6 & 5 & 1 & 0 & 0 & 0 & 3.25 \\
\hline
\end{tabular}

${ }^{a}$ No. of positive samples, ${ }^{b} \mathrm{~A}$ significant $(\mathrm{p}<0.001)$ difference in GMRT was observed using Student's t-test

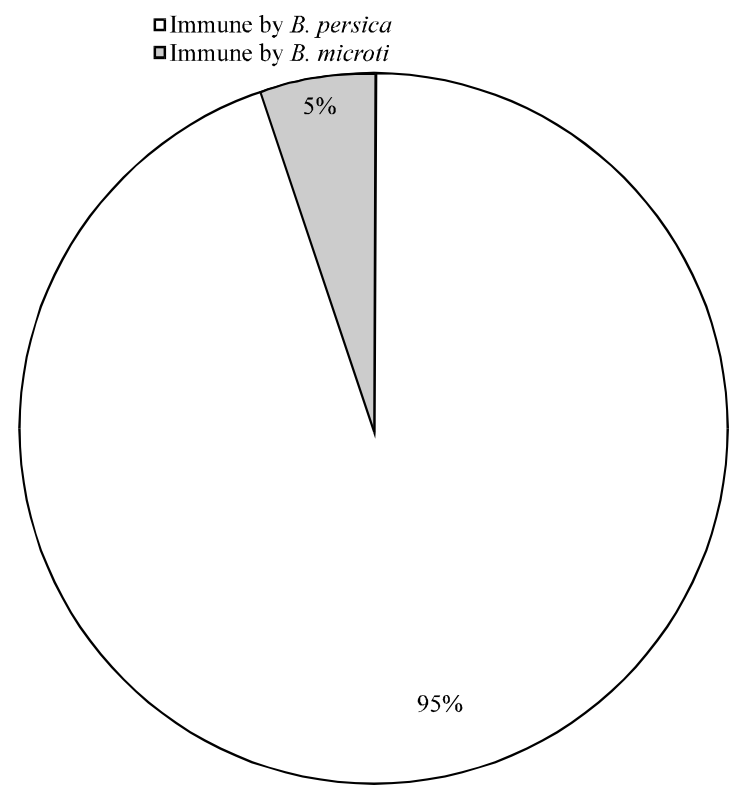

Fig. 5: GMRT of anti Borrelia sera detected by IHA-flagella

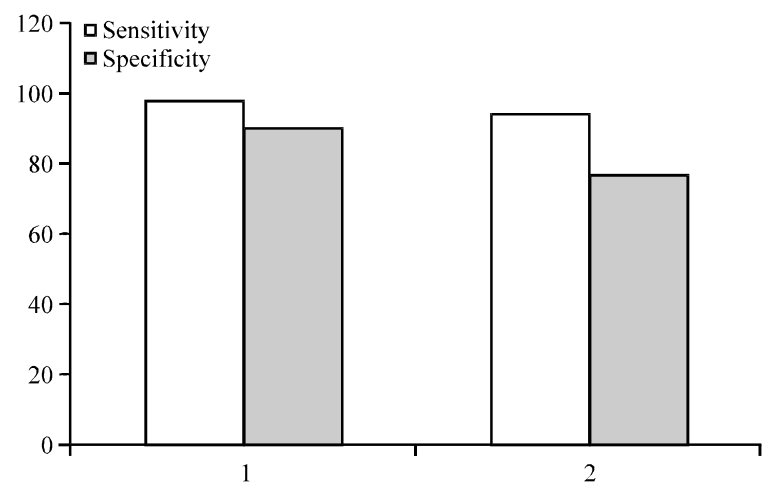

Fig. 6: Comparison of sensitivity and specificity of IHA-flagella with IHA-sonicate

$94 \%$ specificity for IHA flagella and $90 \%$ sensitivity and $76 \%$ specificity for IHA-sonicate kit (Fig. 6).

\section{DISCUSSION}

At present, the best medium for growth of Borrelia is BSK (Barbour et al., 1983).It is comprised of an enrichment medium along with albumin and BSA. Albumin added alone or with animal serum provides long chain fatty acids as Borrelia are unable to cause elongation of stored fatty acids by beta oxidation. The cholesterol present in cell culture medium is required for cell structure and glucose outside cells with phospholipids are used for building cells.

BSK medium was used with $7 \%$ gelatin and $10 \%$ serums of different animals were tested to obtain enough Borrelia for periplasmic flagellar purification (Barbour, 1984).

To date, nobody has reported the in vitro culture of $B$. persica, but we have carried it out for the first time using a modification of BSK medium. Different animal sera were used. The best results for $B$. persica were seen with guinea pig sera and not with others. Gelatin increases the density of the medium which helps in the spiral like growth of the bacteria, but as obtaining this serum is difficult, fetal calf serum which is easier to get was tested and the results though not as good were commendable. Growth time was reached in $11 \mathrm{~h}$. Rabbit serum did not provide appropriate results (Fig. 1, 2). Aeration of the medium was important, culture was carried out in tubes so that the $\mathrm{CO}_{2}$ produced by the spirochete remains in the medium and $\mathrm{CO}_{2}$ is not abundant.

The $42 \mathrm{KD}$ flagellar proteins purified from $B$. presica was strain specific and could distinguish between the two species of relapsing fever in Iran. Its molecular weight which was similar to the one purified from B. microtii (Assmar et al., 2002b) and also close to the $41 \mathrm{KD}$ flagellum obtained from $B$. burgodorferi (Coleman and Benach, 1989). However, very little cross reactivity was seen between antibody positive serums of the two strains of relapsing fever causing Borreleosis. Recently, Lopez et al. (2010) have identified a $57 \mathrm{KD}$ antigen that can discriminate between relapsing fever and Lyme borreliosis but our flagella was species specific distinguishing between relapsing fever strains.

For over a decade, ultrastructural analysis, biochemical isolation and characterization have indicated that the periplasmic flagellar filaments of $B$. burgdorferi differ from those of other spirochetes, being composed primarily of a $41 \mathrm{KD}$ protein. However, a flaA homologue 
of $37 \mathrm{KD}$ of $B$. burgdorferi has been found, it is present at amounts one tenth that of flaB and is used for diagnosis of Lyme disease. A three step detergent treatment ( $1 \%$ triton $\mathrm{X})$ followed by shearing in an omnimixer and cesium chloride gradient ultracentrifugation was used for its purification. (Brahmasha and Greenberg, 1989).

Sarcosyl has also been tested with poor results for flagella purification but SDS was used in this study for the first time with notable results. To date, all work has been carried out on B. burgdoferi responsible for Lyme disease and the only report on borrelia responsible for relapsing fever was in by Assmar et al. (2002b).

For diagnosis of Lyme disease, the first two bands (to appear) is reported to be $41 \mathrm{KDa}$ followed by the outer protein c (ospc) band and / or the one at $39 \mathrm{KDa}$, the last two being highly species specific while the former is not. For detection of IgG, ELISA using flagellar antigen for coating of plate was effective, increasing both specificity and sensitivity of the kit. For detection of $\operatorname{IgM}$, coating with flagellar antigen alone, only increased specificity having no effect on sensitivity (Gabriel et al., 1996).

Some recombinant chimeras containing key sequences from a number of $B$. burgdorferi proteins have been generated containing OspA, OspB, OspC, Fla and p93 (Panelius et al., 2002, 2003). Flagellin Fla or p41 and p93 are two good candidates for serodiagnosis of Lyme disease. This region of $\mathrm{p} 41$ used alone is reported to be very sensitive but not specific enough for detection of Lyme disease. As a component of chimeric constructs, however, it adds significantly to the diagnostic performance of the chimeric antigens (Gomes-Solecki et al., 2000).

Recently, using immunoproteomics, a surface antigen was recognized on Borrelia hermsii which could distinguish between Lyme disease and relapsing fever. One candidate that was identified is a hypothetical protein with a molecular mass of $57 \mathrm{kDa}$ that was designated Borrelia immunogenic protein A (BipA). This protein was further investigated as a potential diagnostic antigen for $B$. hermsii given that it is absent from the B. burgdorferi genome (Lopez et al., 2010). It is very interesting to note that the flagellar antigen purified by us was highly specific and sensitive to $B$. persica, that means it could distinguish between two strains of relapsing fever, upto $98 \%$ sensitivity and $94 \%$ specificity. The IHA kits prepared from the sonicate also could distinguish upto $76 \%$ specificity, between the two strains, but the flagellar protein was $94 \%$ specific. We do not have Lyme disease in Iran, otherwise, kits made from this flagella could easily distinguish between the two strains.

The advantages of this antigen, its stability, strain specificity, the fact that it is the primary one to be recognized by the immune system in recurrent fever and a marker for recovery all of which make it a very good one for diagnosis and prognosis. With the advent of new technologies like proteomics and metabolomics, an analysis of glycosylation of $B$. persica flagellins has been carried out by mass spectrometry, a similar study using $1 \mathrm{HNMR}$ for study of its metabolome can be carried out to get a clearer picture about the dynamics of relapsing fever spirochetes especially B. persica (Zamani et al., 2011; Arjmand et al., 2010).

\section{CONCLUSION}

An invitro culture of Borrelia persica was standardized using different sera with BSK medium. A $42 \mathrm{KD}$ flagellar antigen was purified and an IHA kit was prepared and tested on B. persica and $B$. microtti immunized sera. The kit was seen to be $98 \%$ sensitive and $94 \%$ specific and could easily distinguish between the two close strains of relapsing fever causing Borrelia.

\section{ACKNOWLEDGMENT}

This project was financially supported by a grant from Institute Pasteur of Iran.

\section{REFERENCES}

Arjmand, M., M. Kompany-Zareh, M. Vasighi, N. Parvizzadeh, Z. Zamani and F. Nazgooei, 2010. Nuclear magnetic resonance-based screening of thalassemia and quantification of some hematological parameters using chemometric methods. Talanta, 81: 1229-1236.

Assmar, M., M. Soleimani, F. Oreiz, N. Piazak, S.M. Hossini, R. Saghiri and Z. Zamani, 2002a. Purification of periplasmic flagellar antigen from Borrelia microtti. Scand J. Infect. Dis., 34: 267-272.

Assmar, M., M. Soleimani, N. Piazak, O. Farzad and S.H. Hosseini et al., 2002b. Preparation of a new medium for in vitro culture of Borrelia microtti and Borrelia persica. Med. J. Islam. Repub. Iran, 15: 227-230. 
Barbour, A.G., 1984. Isolation and cultivation of lyme disease spirochetes. Yales. Biol. Med., 57: 521-525.

Barbour, A.G., W. Burgdorferi, S.F. Hayes, O. Peter and A. Aeschlimann, 1983. Isolation of a cultivable spirochete from Ixodes ricinus ticks of Switzerland. Curr. Microbiol., 8: 123-126.

Blum, H., H. Bier and H.J. Gros, 1987. Improved silver staining of plant protein RNA and DNA in polyacrylamide gels. Electrophoresis, 8: 93-99.

Bradford, M.M., 1976. A rapid and sensitive method for the quantitation of microgram quantities of protein utilizing the principle of protein-dye binding. Anal. Biochem., 72: 248-254.

Brahmasha, B. and E.P. Greenberg, 1989. Cloning and sequence analysis of flaA, a gene encoding a spirochete aurantia flagellar filament surface antigen. J. Bacteriol., 171: 1692-1697.

Burbelo, P.D., A.T. Issa, K.H. Ching, J.I. Cohen and M.J. Iadarola et al., 2010. Rapid, simple, quantitative and highly sensitive antibody detection for lyme disease. Clin. Vaccine. Immunol., 17: 904-909.

Burgdorfer, W. and T.G. Schwann, 1999. Borrelia. In: The Manual of Clinical Microbiology. Murray, A.R., E.J. Baron, M.A. Pfaller, F.C. Tenover and H. Yolken.7th (Edn.), American Society of Microbiology, Washington, DC., pp: 365-380.

Coleman, J.L. and J.L. Benach, 1989. Identification and characterization of an endoflagellar antigen of Borrelia. burgdorferi. J. Clin. Invest., 84: 322-330.

Dworkin, M.S., T.G. Schwan, D.E. Anderson and R.S.M. Jr. Borchardt, 2008. Tick-borne relapsing fever. Infect. Dis. Clin. North. Am., 22: 449-468.

Farrah, I.Y., R. Yahia, E. Marva, A. Wilamowski and S.S. Sawalha et al., 2010. Molecular characterization of Borrelia persica, the agent of tick borne relapsing fever in Israel and the Palestinian Authority. PLoS. One., vol. 5.

Gabriel, M.C., R.C. Bernne, J.S. O'Donner and F. Dermerst, 1996. Understanding the western blot. LymeNett Newlett., Vol. 4.

Garon, C.F., 1981. Electron microscopy of nucleic acids. In: Gene Amplification and Analysis. Chijion, J.G. and T.S. Papas (Eds.), Vol. 2, Elsevier, New York, pp: 537-85.

Gomes-Solecki, M.J., J.J. Dunn, B.J. Luft, J. Castillo and D.E. Dykhuizen, 2000. Recombinant chimeric borrelia proteins for diagnosis of Lyme disease. J. Clin. Microbiol., 38: 2350-2535.
Hansen, K., P. Hindersson and N.S. Pederson, 1988. Measurement of antibodies to the Borrelia burgdorferi flagellum improves serodiagnosis in Lyme disease. J. Clin. Microbiol., 26: 338-346.

Herbert, W.J., 1978. Passive haemagglutination with special reference to the tanned cell technique. Handbook. Exp. Immunol., 620: 1-16.

Karimi, Y., K.H. Hougen, B. A. Anderson and M. Assmar, 1979. Borrelia persica and B. Balthazardi sp. Nov: Experimental pathogenicity for some animals and comparison of the ultrastructure. Ann. Microbiol. (Inst Pasteur). 130: 157-168.

LaRocca, T.J. and J.L. Benach, 2008. The important and diverse roles of antibodies in the host response to Borrelia infections. Curr. Topics Microbiol. Immunol., 319: 63-103.

Lopez, J.E., M.E. Schrumpf, V. Nagarajan, S.J. Raffel and B.N. McCoy et al., 2010. A novel surface antigen of relapsing fever spirochetes can discriminate between relapsing fever and Lyme borreliosis. Clin. Vaccine. Immunol., 17: 564-571.

Lopez, J.E., S.F. Porcella, M.E. Schrumpf, S.J. Raffel and C.H. Hammer et al., 2009. Identification of conserved antigens for early serodiagnosis of relapsing fever Borrelia. Microbiology, 155: 2641-2651.

Panelius, J., P. Lahdenne, T. Heikkila, M. Peltomaa and J. Oksi et al., 2002. Recombinant OspC from Borrelia burgdorferi sensu stricto, B. afzelii and $B$. garinii in the serodiagnosis of Lyme borreleosis. J. Med. Microbiol., 5: 731-739.

Panelius, J., P. Lahdenne, H. Saxen, S.A. Carlsson and T. Heikkila et al., 2003. Diagnosis of Lyme neuroborreliosis with antibodies to recombinant proteins DbpA, BBK32 and OspC and VisE IR6 peptide. J. Neurol., 250: 1318-1327.

Panelius, J., A. Ranki, T. Meri, I. Seppala and S. Meri, 2010. Expression and sequence diversity of the complement regulating outer surface protein $\mathrm{E}$ in Borrelia afzelii vs. Borrelia garinii in patients with erythema migrans or neuroborreliosis. Microbial Pathogenesis, 49: 363-368.

Porcella, S.F., S.J. Raffel, D.E. Jr. Anderson, S.D. Gilk, J.L. Bono, M.E. Schrumpf and T.G. Schwan, 2005. Variable tick protein in two genomic groups of the relapsing fever spirochete Borrelia hermsii in Western North America. Infect. Immun., 73: 6647-6658.

Schwann, T.G. and B.J. Hinnebush, 1998. Bloodstream versus tick associated variants of a relapsing fever bacterium. Science, 280: 1938-1940. 
Sherris, J.C., Ryan, K.J. and C.L. Ray, 2004. Sherri's Medical Microbiology: An Introduction to Infectious Diseases. McGraw-Hil, New York

Stoenner, H.G., Dodd and T. Larsen, 1982. C. Antigenic variation of B.hermsii. J. Exp. Med., 156: 12973-3000.

Wojciechowska-Koszko, I., I. Maczynska, Z. Szych and S. Giedrys-Kalemba, 2011. Serodiagnosis of borreliosis: Indirect immunofluorescence assay, enzyme-linked immunosorbent assay and immunoblotting. Arch. Immunol. Ther. Exp., 59: 69-77.
Zamani, Z., M. Arjmand, M. Tafazzoli, A. Gholizadeh and F. Pourfallah et al., 2011. Early detection of immunization: A study based on an animal model using ${ }^{1} \mathrm{H}$ nuclear magnetic resonance spectroscop. Pak. J. Biol. Sci., 14: 195-203. 